An Examination of the Role of First-Year College-Level Mathematics in STEM Field Major

Persistence at a Hispanic-Serving Institution

Jaimi Paschal

California State University, Bakersfield

Amanda Taggart

Utah State University 


\begin{abstract}
This study examined the influence of mathematics course-taking on Latina/o science, technology, engineering, and mathematics (STEM) major persistence utilizing data from firstyear STEM majors at a Hispanic-Serving Institution (HSI). Findings indicated that students who passed a first-term college-level mathematics course had significantly greater odds of persisting in STEM majors than those who did not, demonstrating the importance of early mathematics support to increased STEM major persistence.
\end{abstract}

Keywords: STEM, Latina(o), Hispanic-Serving Institution, retention, mathematics 


\section{An Examination of the Role of First-Year College-Level Mathematics in STEM Field Major Persistence at a Hispanic-Serving Institution}

Of the approximately 1.9 million bachelor's degrees conferred by colleges and universities in the United States during the 2015-2016 school year, 18\% were conferred in science, technology, engineering, and mathematics (STEM) fields (McFarland et al., 2018). However, this number reflects roughly half the college students who were originally interested in completing STEM degrees (Center for Institutional Data Exchange and Analysis, 2000), with $48 \%$ of STEM field majors leaving those majors before graduating from college (Chen, 2013). With jobs in STEM fields growing at double the speed of other jobs and 73\% of jobs in STEM fields requiring bachelor's degrees (Fayer, Lacey, \& Watson, 2017), the demand for STEM bachelor's degree holders exceeds the pool of qualified workers.

As such, there have been calls for institutions of higher education to increase baccalaureate attainments in STEM fields to help the United States to remain economically competitive (Olson \& Riordan, 2012). For instance, a 2012 report by the President's Council of Advisors on Science and Technology called for an increase of 1 million college graduates in STEM disciplines to combat the nation's government job shortage forecast for the following 10 years (Iammartino, Bischoff, Willy, \& Shapiro, 2016). Furthermore, Carnevale, Smith, and Strohl's (2013) report on workforce recovery after the 2007 recession suggested that institutions of higher education needed to increase the graduation rates of STEM field majors to fill 4 million job vacancies in high-demanding STEM fields.

In addition to the high attrition rates of STEM field majors in general, there is an even lower percentage of underrepresented minority (URM) students who graduate with bachelor's degrees in STEM fields, with Latina/o, Black, and Native American students earning STEM 
degrees at lower rates than their Asian and White counterparts (McFarland et al., 2018). Among URM students, Latinas/os are less likely to persist in college than their White, Asian, and Black peers (Stewart, Lim, \& Kim, 2015) and have the lowest rates of bachelor's degree completion among all racial/ethnic groups (Musu-Gillette et al., 2016). This is especially worrisome given that Latina/o student college enrollment increased 180\% between 1999 and 2016, outpacing enrollment growth for all other racial/ethnic groups in the United States (Gramlich, 2017). In addition, Latinas/os currently make up the largest racial/ethnic minority in the United States and constitute the fastest-growing group of any sector in the nation with an estimated total population projection of nearly $30 \%$ by the year 2060 (U.S. Census Bureau, 2017).

Due to these rapid demographic changes in the nation's population, and therefore its workforce, goals to increase the number of STEM workers in the United States cannot be met without also increasing the number of URM students majoring in STEM fields in American colleges and universities. Doing so will not only fill a void in the U.S. job market in highdemand STEM occupations such as biomedical engineering, forensic science, computer systems analysis, and software development (Fayer et al., 2017), but will also benefit URM workers, as STEM graduates are more likely to be employed full-time than graduates in non-STEM fields (Cataldi, Siegel, Shepherd, \& Cooney, 2014) and are more likely to earn more, as the average STEM job salary is almost twice as much as the average non-STEM salary (Fayer et al., 2017). In response to the demand to increase graduation rates, as well as numbers of qualified workers, in STEM fields, especially among URM students, this study seeks to identify the factors influencing persistence in STEM field majors at a Hispanic-Serving Institution (HSI), where nearly $60 \%$ of all students identify as Latina/o. More explicitly, this study used logistic regression to (a) descriptively compare the background, high school, and college experiences of 
college students who do and do not persist in STEM field majors at an HSI and (b) understand the role of first-term college-level mathematics course-taking on STEM field major persistence among this population. Such a study is important to help colleges and universities develop interventions and supports to increase STEM graduation rates among URM, and especially Latina/o, students and thus increase the number of skilled STEM workers who can contribute to the nation's economic health. Moreover, this study contributes to the current literature on STEM field major persistence by examining Latina/o STEM field majors at an HSI, a population that is currently understudied in the STEM literature.

\section{Conceptual Framework and Related Literature}

The following section offers a conceptual framework for the variables used in the logistic model, which hypothesizes that college students' persistence in STEM field majors is associated with demographic variables such as gender, race/ethnicity, and socioeconomic status (SES);

precollege variables such as high school academic achievement; and college variables such as taking and passing a first-term college-level mathematics course. The variables used in our model were selected from those used in previous research studies on college student persistence in STEM field majors, with the addition of college-level mathematics course-taking, which is a variable that will extend the research in this field.

Among all U.S. college students who earned bachelor's degrees in 2015-2016, 12.8\% were Latina/o students, while the percentage of students who earned bachelor's degrees in STEM was 10.9\% Latina/o (Snyder, de Brey, \& Dillow, 2019). However, HSIs, where approximately half of all Latina/o college students are enrolled but which represent around $8 \%$ of all postsecondary institutions in the United States, confer close to $40 \%$ of all bachelor's degrees earned by Latina/o students (Dowd, Malcom, \& Bensimon, 2009) and one fifth of Latina/o 
student STEM degrees (Dowd, Malcom, \& Macias, 2010). Given this information, it is important to examine the literature to date on the association between STEM field major persistence and HSIs, though this body of work is very small and mainly descriptive in nature (e.g., AguirreCovarrubias, Arellano, \& Espinoza, 2015; Carpi, Ronan, Falconer, Boyd, \& Lents, 2013). Therefore, the following literature review will focus mainly on STEM field major persistence at any type of postsecondary institution and will include work on HSIs where that limited research is available.

A review of the literature revealed several factors that contribute to student persistence in STEM field majors at the postsecondary level, including demographic variables, precollege variables, and college variables. In regard to demographic variables, previous research has identified gender and race/ethnicity as contributors to STEM field major persistence. Concerning gender, female students have been shown to be less likely to declare (e.g., Griffith, 2010) and persist in STEM field majors than male students (e.g., Chen, 2013), other than in the biological sciences (National Science Board, 2018). For example, in a study investigating the factors that influenced students' decisions to declare, persist in, and earn STEM degrees at a large, doctoralgranting HSI, females were less likely to earn STEM degrees than were males (Crisp, Nora, \& Taggart, 2009). Apart from female underrepresentation, URM students (e.g., Latina/o, Black, American Indian) are also underrepresented among STEM field majors (Griffith, 2010).

Among the precollege variables that have been found to be related to college student persistence in STEM field majors, high school academic achievement is one of the most prevalent. In particular, high school grade point average (GPA) and SAT/ACT scores have been shown to contribute to college student persistence in STEM field majors, with students who have higher GPAs and test scores being more likely to persist (e.g., Chen, 2013; Leuwerke, Robbins, 
Sawyer, \& Hovland, 2004; Nguyen, Williams, \& Ludwikowski, 2017), including at an HSI, where an increase in the SAT math score also increased the odds of earning a degree in a STEM field major (Crisp et al., 2009). In regard to college variables, taking and passing college mathematics or other STEM courses have been shown to contribute to persistence in STEM field majors (Chen, 2013; Chen \& Ho, 2012). In addition to just passing a class, students in STEM field majors who earn higher grades in STEM classes are also more likely to persist in those majors (e.g., Honken \& Ralston, 2013; Maltese \& Tai, 2011; Rask, 2010).

As noted in the literature review, previous research has been conducted on the influence of college mathematics course-taking on the persistence of STEM field majors. However, to date, the bulk of the literature on this topic has centered on calculus-ready students, who are more likely to persist in STEM field majors (e.g., Bressoud, Mesa, \& Rasmussen, 2015), or students taking remedial mathematics courses, who are less likely to persist in STEM field majors (e.g., Bahr, 2013). This study bridges a gap in the literature by focusing on students majoring in STEM fields who begin college by taking college-level (i.e., non-remedial), noncalculus mathematics, which may include courses such as college algebra, statistics, and trigonometry. In addition, with the exception of Crisp et al. (2009), there has been very limited research examining the influence of college mathematics course-taking on Latina/o student persistence in STEM field majors at an HSI. According to the National Science Board (2018), “Minority-serving institutions play an important role in underrepresented minorities' education and career pathways" (Chap. 2, p. 4). As such, based on the rapidly growing Latina/o population in the United States and the demonstrated need to increase the participation of this population in the national STEM workforce, this study follows the recommendation of Garcia and Hurtado (2011) that "Empirical research is needed to understand the factors that predict persistence for 
Latina/o college students pursuing STEM field majors" (p. 3). In turn, the following research questions guided this study.

1. Research Question 1: Are there differences between the characteristics of college students at an HSI who do and do not persist in STEM field majors through the second college year? 2. Research Question 2: What is the contribution of demographic variables, pre-college variables, and college variables to persistence in STEM field majors at an HSI through the second college year?

\section{Method}

\section{Data Collection and Sample}

This study examined archival data from an open-access, 4-year HSI in the western United States. The student population at this school consists of $64 \%$ URM students, with $58 \%$ of those students identifying as Latina/o. The majority of students at the university are first-generation college students $(60 \%)$, and $47 \%$ of all students graduate in 6 years or less. The university covers a large, somewhat geographically isolated region with low educational attainment rates and high rates of poverty. In addition, more than $70 \%$ of the institution's alumni remain to live and work in the region after graduation, making the university a major contributor to the economic development of the area. The largest employers in the region focus on agriculture and oil. This makes the university under study a prime candidate for examining STEM field major persistence among Latina/o students, as there are expected to be almost 2 million job opportunities in the oil, natural gas, and petrochemical industries through 2035 (IHS Global Inc., 2016).

The study analyzed all first-time freshmen enrolled in the university between the fall 2008 and fall 2013 terms with declared STEM field majors whose records had no missing data ( $n$ $=708$ ). At the time of matriculation, all the participants met college-ready mathematics 
requirements (i.e., they did not require mathematics remediation) during their first college term. Descriptive statistics and logistic regression were utilized to examine the characteristics of students and variables that contributed to students persisting in a STEM field major through their second college year versus students not persisting in a STEM field major through their second college year.

The decision to study the persistence of first-time freshman students with declared STEM field majors at the time of matriculation through the second college year was made because the end of the sophomore year is the point at which most universities encourage or require students to officially declare a major field. Therefore students that may be discouraged from their intended major in a STEM field are likely to choose another major by the end of their sophomore year and in fact, much of the attrition by intended STEM field majors occurs within the first two years of college. A smaller percentage then switches away from STEM field majors between their sophomore and senior years (Griffith, 2010, p. 916).

\section{Predictor Variables}

Six variables were hypothesized to influence a freshman student's persistence in a STEM field major through the second college year. Three demographic variables were included in the model, including students' gender, race/ethnicity, and SES. Race/ethnicity was self-reported and students were grouped into one of two racial/ethnic categories: (a) URM (Hispanic/Latina/o, Black or African American, American Indian/Alaska Native, Native Hawaiian or Other Pacific Islander), with Latina/o students making up just over $89 \%$ of all URM students or (b) non-URM (White or Asian). Asian students were included in the non-URM category because they are overrepresented in STEM field majors (e.g., McFarland et al., 2018). Gender included a 
student's legally assigned sex as either male or female. The federally reported Expected Family Contribution (EFC), collected by the university's financial aid department, was used as an indicator of SES.

Two precollege variables, high school GPA and the determinants in high school that regulated student placement in a mathematics course in college, were used in this study. Cumulative high school GPA, based on a 4.00 scale, was rounded to the nearest hundredth. Placement into a first-term college-level mathematics course was included in the study to analyze if certain types of placement methods predicted more success for students in a first-term college-level mathematics class. Placement was determined according to university policy by a student's completion of one of the following: (a) a score on the entry-level mathematics (ELM) placement exam that placed the student in a college-level mathematics course; (b) a qualifying score on the ACT exam; (c) a qualifying score on the mathematics portion of the SAT I exam; (d) a qualifying score on the SAT mathematics (SAT-M) subject exam; (e) a qualifying score on the advanced placement (AP) exam for Calculus $\mathrm{AB}$ or Calculus $\mathrm{BC}$; (f) passing one remedial mathematics course in a summer bridge program at the university of study; (g) passing two remedial mathematics courses in a summer bridge program at the university of study; (h) completing a university-sponsored summer course to fulfill the remedial mathematics requirement prior to the start of the first college term; (i) completing a high school early assessment program and passing 4 years of high school mathematics courses, including one college-level mathematics course; or (j) placement into a college-level mathematics course not otherwise specified.

The college variables included in the model were taking and passing a first-term collegelevel mathematics course below calculus. Specifically, students who passed a first-term college- 
level mathematics course below calculus were studied versus students who did not take or did not pass a first-term college-level mathematics course below calculus. First-time college freshmen who declared STEM field majors upon matriculation but who did not take a mathematics course during their first college term were included with students who did not pass their first-term college-level mathematics course.

\section{Outcome Variable}

The dichotomous outcome examined in this study was whether students persisted in a STEM field major through the second college year versus whether they did not persist in a STEM field major through the second college year.

\section{Data Analysis}

Frequencies were computed to explore and compare the characteristics of students who were retained in a STEM field major through the second college year with those students who were not retained in a STEM field major through the second college year. In addition, a regression model was used to examine the relationship between the dichotomous (persisted vs. not persisted) dependent variable and the set of predictor variables. Logistic regression was chosen as the method of data analysis because the study involved a dichotomous dependent variable and multiple independent variables (Hosmer, Lemeshow, \& Sturdivant, 2013). Interactions between each dichotomous variable were performed to test for collinearity. The final logistic regression model was determined by utilizing backward model selection. The final model used the Wald chi-square statistic and $p$ values to determine model fit statistical significance (Hosmer et al., 2013); $\mathrm{p}<.05$ was used to determine whether the predictor variables were significantly related to the dependent variable. In addition, a parameter estimate was run to 
determine whether the study sample means were indicative of the entire population (Hosmer et al., 2013).

\section{Results}

The subsequent section describes the findings from our statistical analysis, as guided by our conceptual framework which hypothesized that persistence in a STEM field major is influenced by demographic variables such as gender, race/ethnicity, and SES; precollege variables such as high school academic achievement and mathematics placement methods; and college variables such as taking and passing a first-term mathematics course.

\section{Descriptive Findings}

A descriptive comparison of students retained in a STEM field major through their second college year $(n=334)$ versus students who were not retained in a STEM field major through their second college year $(n=374)$ revealed numerous demographic differences between the two groups. Female and male students were retained at almost identical rates, as were students classified as low-SES and students not classified as low-SES (48\% females vs. 47\% males; 47\% low-SES vs. 48\% not low-SES). In addition, non-URM students outnumbered URM students as retained in a STEM field major through their second college year (58\% vs. 42\%).

Descriptive findings also revealed noteworthy results regarding the two precollege variables from the conceptual model. Students entering college with a high school GPA of 3.50 or higher outnumbered students entering college with a high school GPA of 3.49 or lower in being retained in a STEM field major through their second college year (76\% vs. 48\%). Also, students who passed a first-term college-level mathematics course below calculus were retained in a STEM field major at a higher rate than students who did not take or pass a first-term collegelevel mathematics course (59\% vs. $34 \%)$. 
Concerning mathematics course placement in the first college term, students who placed into a first-term college-level mathematics course below calculus by earning a passing score of 3 or higher on the AP Calculus exam or by passing a remedial mathematics requirement through a summer bridge program outside the institution of study showed higher rates of retention in a STEM field major through the second college year when compared with the other means by which a student could place. Descriptive findings are summarized in Table 1.

[Insert Table 1 here]

\section{Logistic Regression Analysis}

Table 2 displays the parameter estimates, significance values, standard errors, odds ratios, and fit statistics for the regression model. The final model indicated that, of the six predictor variables and six two-way interactions, two (i.e., race/ethnicity, students who took and passed a college-level mathematics course below calculus during their first term in college) showed a statistically significant effect on the prediction of STEM retention through the second college year. The overall fit of the model was found to be significant at $p<.05$ and yielded correct predictions for $50 \%$ of the model.

[Insert Table 2 here]

A review of the results indicated that students who took and passed a first-term collegelevel mathematics course below calculus increased their odds of retention in a STEM field major through the second college year by a factor of 2.79. Furthermore, URM students showed decreased odds of retention in a STEM field major through the second college year by a factor of 0.65 .

\section{Discussion}

\section{Implications}


Findings from this study contribute to our understanding of the factors influencing college student persistence in STEM field majors at an HSI. The study extends previous work on this subject by examining the impact of taking a first-term college-level mathematics course below calculus on the persistence of students in STEM field majors, particularly among URM students. Descriptive findings revealed some differences from prior research in this area, specifically regarding gender and SES. For example, the results of this study showed that there was almost no difference in the STEM field major persistence rates of male and female students, contrasting previous work that found female students to be less likely to persist in STEM field majors than male students (Chen, 2013; Crisp et al., 2009; Griffith, 2010). Moreover, this study found almost no difference in the persistence rates of students from low-SES backgrounds and students not from low-SES backgrounds. This finding is very similar to the data for high school students in the area, as the university under study draws its student population from the surrounding geographic area and the achievement results of the state-mandated standardized mathematics assessment from the high schools in that area show that the differences in percentages of students who pass that test, as disaggregated by gender and economic disadvantage, are also separated by only a few percentage points.

Similar to previous research (Chen, 2013; Chen \& Soldner, 2014), descriptive results revealed the importance of high school GPA on student persistence in STEM field majors, as students with higher GPAs persisted in STEM field majors at greater rates than students with lower GPAs. Because the university that served as the site of this study does not require students to take prerequisites and does not consider high school GPA before allowing students to declare a STEM major, it is recommended that this institution and others like it implement certain scaffolds for students with lower high school GPAs. For instance, such schools could require 
students with low high school GPAs to complete certain STEM prerequisite courses and earn a "B" average in such courses before allowing them to officially declare STEM field majors.

The results of the logistic regression analysis revealed that majority Latina/o URM students are 35\% less likely to persist in STEM field majors than are non-URM students. These findings are consistent with prior studies focused on the influence of race/ ethnicity on persistence in STEM field majors that showed majority-Latina/o URM students persisting in STEM field majors at lower rates than non-URM students (Alkhawawneh \& Hargraves, 2014; Chen, 2013; Chen \& Ho, 2012; Kokkelenberg \& Sinha, 2010). However, given that previous research has also shown that Latina/o students attending HSIs are more likely to declare STEM field majors than their non-Latina/o peers (Crisp et al., 2009), it is critical that postsecondary institutions work to find ways to support Latina/o students in their journey from declaring a STEM field major to persisting in that STEM field major through graduation.

In regard to the role of mathematics course-taking on persistence in STEM field majors, this study found that freshman students were nearly 3 times more likely to persist in STEM field majors when they passed a college-level mathematics course below calculus in their first college term. Although much of the prior work on STEM field major persistence has focused on general academic performance (e.g., Allen \& Robbins, 2008) and mathematics success (e.g., Gilmer, 2007), this study identifies a specific term that influences persistence in STEM field majors, indicating that achievement at the very beginning of students' college careers may impact their STEM persistence. This finding is important given that previous research has shown that early intervention to improve mathematics skills leads to success in subsequent mathematics courses (Goonatilake \& Chappa, 2010; Harrington, Lloyd, Smolinski, \& Shahin, 2016), many of which are required in various STEM fields. 
According to Carpi et al. (2013), "Underfunded, public, minority-serving institutions are constrained in terms of the support services they can offer students. Yet these are precisely the institutions most commonly attended by students who require the most academic support" (p. 295). Therefore, it is important that institutions of higher education increase support for beginning URM college students with declared STEM field majors in college-level mathematics courses. For instance, it is recommended that college administrators ensure mathematics faculty are aware of the relationship between first-term mathematics success and persistence in STEM so they can not only work to find ways to overcome the challenges facing URM STEM field majors, but so they can understand the significance of offering additional mathematics support to freshman students rather than embracing the all-too-common philosophy of "weeding out" new college students during their first college term.

In addition, the results of this study could help decision makers at the university, college, and department levels determine course-taking requirements and timelines for STEM field majors that would best help them persist in such majors. By focusing on term-to-term mathematics course-taking patterns, faculty and administrators could implement strategic retention models to increase STEM graduation rates (Haemmerlie \& Montgomery, 2012) and thus supply qualified workers for crucial, in-demand jobs in STEM fields.

\section{Recommendations for Future Research}

Given the results of this study, it is recommended that future research examine which interventions for mathematics support are most effective specifically for Latina/o students. Although there does exist a limited amount of literature outlining various recommendations for how colleges and universities can increase student success in mathematics, this work often relies on descriptions of current programs rather than on empirical research analyzing the effectiveness 
of the supports described (e.g., Bressoud et al., 2015). For example, authors have described practices that have been implemented at a minority-serving institution on the East Coast to increase retention in STEM field majors for URM students, including paced science courses, curricular alignment between mathematics and science courses, a peer mentoring program, and intrusive advising (Carpi et al., 2013), though, as mentioned previously, this work relies primarily on program descriptions rather than on empirical analysis of the supports or interventions that have been enacted.

In addition, future research should examine what inhibits URM students' persistence in STEM field majors so that faculty and administrators can work to overcome these barriers for students in vulnerable populations, including Latina/o students attending HSIs, as in this study. Finally, because the results of this research showed that students at an HSI were much more likely to persist in STEM field majors when they passed a college-level mathematics course in their first college term, it is recommended that additional research be conducted to study whether persistence in STEM field majors differs for students who delay college-level mathematics course-taking until later in their college careers.

\section{Limitations}

This study contains certain limitations, including the possibility that college students could change their majors from the time of matriculation to the second college year without changing their declaration in the university system, which could impact the percentage of students listed as retained who actually may not have been retained. Furthermore, this research omitted additional precollege and college variables previously found in the literature to be predictors of student retention in STEM field majors (e.g., last mathematics course taken in high school, delimitation between students who dropped out of college versus students who changed 
from STEM to non-STEM field majors) that could have yielded additional results. These variables were not included in this study because the university that served as the site of this research could not provide them. Moreover, this study investigated persistence in a STEM field major only through the second college year but did not look at retention in a STEM field major through college graduation. Doing so does not account for students who change their majors later in their college careers. 


\section{References}

Aguirre-Covarrubias, S., Arellano, E., \& Espinoza, P. (2015). “A pesar de todo” (despite everything): The persistence of Latina graduate engineering students at a HispanicServing Institution. New Directions for Higher Education, 172, 49-57. doi:10.1002/he.20152

Alkhawawneh, R., \& Hargraves, R. H. (2014). Developing a hybrid model to predict student first year retention in STEM disciplines using machine-learning techniques. Journal of STEM Education, 15(3), 35-42.

Allen, J., \& Robbins, S. B. (2008). Prediction of college major persistence based on vocational interests, academic preparation, and first-year academic performance. Research in Higher Education, 49, 62-79. doi:10.1007/s11162-007-9064-5

Bahr, P. R. (2013). The aftermath of remedial mathematics: Investigating the low rate of certificate completion among remedial mathematics students. Research in Higher Education, 54, 171-200. doi:10.1007/s11162-012-9281-4

Bressoud, D., Mesa, V., \& Rasmussen, C. (Eds.). (2015). Insights and recommendations from the MAA national study of college calculus. Retrieved from http://www.maa.org/sites/ default/files/pdf/cspcc/InsightsandRecommendations.pdf

Carnevale, A., Smith, N., \& Strohl, J. (2013). The road to recovery: Projecting U.S. job growth and higher education demand through 2020. Community College Journal, 84(3), 26-29.

Carpi, A., Ronan, D. M., Falconer, H. M., Boyd, H. H., \& Lents, N. H. (2013). Development and implementation of targeted STEM retention strategies at a Hispanic-Serving Institution. Journal of Hispanic Higher Education, 12, 280-299. doi:10.1177/1538192713486279 
Cataldi, E. F., Siegel, P., Shepherd, B., \& Cooney, J. (2014). Baccalaureate and beyond: A first look at the employment experiences and lives of college graduates, 4 years on (B\&B:08/12) (NCES 2014-141). Retrieved from https://nces.ed.gov/pubs2014/2014141.pdf

Center for Institutional Data Exchange and Analysis. (2000). 1999-2000 STEM retention report: The retention and graduation rates of 1992-98 entering science, mathematics, engineering and technology majors in 119 colleges and universities. Norman: University of Oklahoma.

Chen, X. (2013). STEM attrition: College students' paths into and out of STEM fields (NCES 2014-001). Retrieved from https://nces.ed.gov/pubs2014/2014001rev.pdf

Chen, X., \& Ho, P. (2012). STEM in postsecondary education: Entrance, attrition, and course taking among 2003-04 beginning postsecondary students (NCES 2003-152). Washington, DC: U.S. Department of Education, National Center for Education Statistics. Retrieved from https://nces.ed.gov/pubs2013/2013152.pdf

Chen, X., \& Soldner, M. (2014). STEM attrition: College students' paths into and out of STEM fields. Retrieved from https://nces.ed.gov/pubs2014/2014001rev.pdf

Crisp, G., Nora, A., \& Taggart, A. (2009). Student characteristics, pre-college, college, and environmental factors as predictors of majoring in and earning a STEM degree: An analysis of students attending a Hispanic Serving Institution. American Educational Research Journal, 46, 924-942. doi:10.3102/0002831209349460

Dowd, A. C., Malcom, L. E., \& Bensimon, E. M. (2009). Benchmarking the success of Latina and Latino students in STEM to achieve national graduation goals. Los Angeles: University of Southern California. 
Dowd, A. C., Malcom, L. E., \& Macias, E. E. (2010). Improving transfer access to STEM bachelor's degrees at Hispanic Serving Institutions through the America COMPETES Act. Los Angeles: University of Southern California.

Fayer, S., Lacey, A., \& Watson, A. (2017). STEM occupations: Past, present, and future. Retrieved from https://www.bls.gov/spotlight/2017/science-technology-engineering-andmathematics -stem-occupations-past-present-and-future/pdf/science-technologyengineering-and -mathematics-stem-occupations-past-present-and-future.pdf

Garcia, G. A., \& Hurtado, S. (2011). Predicting Latina/o STEM persistence at HSIs and nonHSIs. Paper presented at the annual meeting of the American Educational Research Association, New Orleans, LA held in April. Retrieved from https:/heri.ucla.edu/publications/

Gilmer, T. C. (2007). An understanding of the improved grades, retention and graduation rates of STEM majors at the Academic Investment in Mathematics and Science (AIMS) program of Bowling Green State University (BGSU). Journal of STEM Education, 8(1-2), 11-21.

Goonatilake, R., \& Chappa, E. (2010). Early intervention in college mathematics courses: A component of the STEM RRG program funded by the US Department of Education. Montana Mathematics Enthusiast, 7, 63-74.

Gramlich, J. (2017, September 29). Hispanic dropout rate hits new low, college enrollment at new high. Retrieved from www.pewresearch.org/fact-tank/2017/09/29/hispanic-dropoutrate-hits-new-low-college-enrollment-at-new-high/

Griffith, A. L. (2010). Persistence of women and minorities in STEM field majors: Is it the school that matters? Economics of Education Review, 29, 911-922. doi:10.1016/j.econedurev.2010.06.010 
Haemmerlie, F. M., \& Montgomery, R. L. (2012). Gender differences in the academic performance and retention of undergraduate engineering majors. College Student Journal, 46(1), 40-45.

Harrington, M., Lloyd, A., Smolinski, T., \& Shahin, M. (2016). Closing the gap: First year success in college mathematics at an HBCU. Journal of the Scholarship of Teaching and Learning, 16(5), 92-106. doi:10.14434//josotl.v16i5.19619

Honken, N., \& Ralston, P. (2013). Freshman engineering retention: A holistic look. Journal of STEM Education, 14(2), 29-37.

Hosmer, D. W., Jr., Lemeshow, S., \& Sturdivant, R. X. (2013). Applied logistic regression (3rd ed.). Hoboken, NJ: John Wiley.

Iammartino, R., Bischoff, J., Willy, C., \& Shapiro, P. (2016). Emergence in the U.S. Science, Technology, Engineering, and Mathematics (STEM) workforce: An agent-based model of worker attrition and group size in high-density STEM organizations. Complex \& Intelligent Systems, 2, 23-34. doi:10.1007/s40747-016-0015-7

IHS Global Inc. (2016). Minority and female employment in the oil \& natural gas and petrochemical industries, 2015-2035. Retrieved from https://www.api.org/ /media/Files/Policy/Jobs/16-March-Women-MinoritiesJobs/Minority-and-Female-Employment-2015-2035. pdf

Kokkelenberg, E. C., \& Sinha, E. (2010). Who succeeds in STEM studies? An analysis of Binghamton University undergraduate students. Economics of Education Review, 29, 935-946. doi:10.1016/j.econedurev.2010.06.016 
Leuwerke, W. C., Robbins, S., Sawyer, R., \& Hovland, M. (2004). Predicting engineering major status from mathematics achievement and interest congruence. Journal of Career Assessment, 12, 135-149. doi:10.1177/1069072703257756

Maltese, A. V., \& Tai, R. H. (2011). Pipeline persistence: Examining the association of educational experiences with earned degrees in STEM among U.S. students. Science Education, 95, 877-907. doi:10.1002/sce.20441

McFarland, J., Hussar, B., Wang, X., Zhang, J., Wang, K., Rathbun, A., \& . . Mann, F. (2018). The condition of education 2018 (NCES 2018-144). Retrieved from https://nces.ed.gov/ pubsearch/pubsinfo.asp?pubid=2018144

Musu-Gillette, L., Robinson, J., McFarland, J., KewalRamani, A., Zhang, A., \& WilkinsonFlicker, S. (2016). Status and trends in the education of racial and ethnic groups 2016 (NCES 20116-007). Retrieved from https://nces.ed.gov/pubs2016/2016007.pdf

National Science Board. (2018). Science and Engineering Indicators 2018 (NSB-2018-1).

Alexandra, VA: National Science Foundation. Retrieved from https://www.nsf.gov/statistics/indicators/

Nguyen, T. K., Williams, A., \& Ludwikowski, W. M. (2017). Predicting student success and retention at an HBCU via interest-major congruence and academic achievement. Journal of Career Assessment, 25, 552-566. doi:10.1177/1069072716651870

Olson, S., \& Riordan, D. G. (2012). Engage to excel: Producing one million additional college graduates with degrees in science, technology, engineering, and mathematics. Report to the President of the United States. President's Council of Advisors on Science and Technology. Retrieved from https://files.eric.ed.gov/fulltext/ED541511.pdf 
Rask, K. (2010). Attrition in STEM fields at a liberal arts college: The importance of grades and pre-collegiate preferences. Economics of Education Review, 29, 892-900. doi:10.1016/j. econedurev.2010.06.013

Snyder, R. D., de Brey, C., \& Dillow, S. A. (2019). Digest of education statistics 2017 (NCES 2018-070). Retrieved from https://nces.ed.gov/pubs2018/2018070.pdf

Stewart, S., Lim, D. H., \& Kim, J. (2015). Factors influencing college persistence for first-time students. Journal of Developmental Education, 38(3), 12-20.

U.S. Census Bureau. (2017). Profile America facts for features (CB17-FF.17). Retrieved from https://www.census.gove/content/dam/Census/newroom/facts-for-features/2017/cb17ff17 .pdf 


\section{Table 1}

Descriptive Comparison of Students Persisting in a STEM Field Major Versus Not Persisting in a STEM Field Major

$$
\begin{aligned}
& \% \text { of students who } \% \text { of students who did not } \\
& \text { persisted }(n=334) \quad \text { persist }(n=374)
\end{aligned}
$$

Demographic variables

Gender

Male

Female

Race/ethnicity

URM

Non-URM

\section{SES}

Low-SES

Not low-SES

Precollege variables

High school GPA

3.5 or higher

College mathematics course placement criteria

SAT score

SAT-math score

0

100

ACT score

54

46

AP Calculus exam score

60 
University math entry test score

Passed remedial math at institution's summer bridge

program

Passed remedial math at outside institution's summer bridge program

Passed two remedial math courses at institution's summer bridge program

Passed institution's summer math course

Passed 4 years of high school math, including collegelevel math

Completed other requirements

College variables

First-term college-level mathematics course

Passed course

Did not take or pass course
Note. STEM = science, technology, engineering, and mathematics; URM = underrepresented minority; SES = socioeconomic status; GPA = grade point average; AP = advanced placement. 


\section{Table 2}

Logistic Regression Model: Parameter Estimates and Model Evaluation Predicting Students' Persistence in STEM Field Majors

\begin{tabular}{|c|c|c|c|}
\hline & $\beta$ & $\mathrm{SE}$ & Odds ratio $^{\mathrm{a}}$ \\
\hline \multicolumn{4}{|l|}{ Demographic variables } \\
\hline \multicolumn{4}{|l|}{ Gender } \\
\hline Female & -1.348 & 0.482 & \\
\hline \multicolumn{4}{|l|}{ Male } \\
\hline \multicolumn{4}{|l|}{ Race/ethnicity } \\
\hline URM & $-0.434^{*}$ & 0.161 & 0.648 \\
\hline \multicolumn{4}{|l|}{ Non-URM } \\
\hline \multicolumn{4}{|l|}{ SES } \\
\hline Not low-SES & -0.231 & 0.520 & \\
\hline \multicolumn{4}{|l|}{ Low-SES } \\
\hline \multicolumn{4}{|l|}{ Precollege variables } \\
\hline High school GPA & 0.341 & 0.175 & \\
\hline \multicolumn{4}{|c|}{$\begin{array}{l}\text { College mathematics course placement } \\
\text { criteria }\end{array}$} \\
\hline SAT score & 0.411 & 0.334 & \\
\hline SAT-math score & -11.328 & 254.1 & \\
\hline ACT score & 0.892 & 0.608 & \\
\hline
\end{tabular}


AP Calculus exam score

University math entry test score

Passed remedial math at institution's summer bridge program

Passed remedial math at outside institution's summer bridge program

Passed two remedial math courses at institution's summer bridge program

Passed institution's summer math course

Passed 4 years of high school math, including college-level math

Completed other requirements

College variables

First-term college-level mathematics course

Passed course

$1.027^{*}$

0.157

2.794

Did not take or pass course

Collinearity tests

First-Term College-Level Mathematics

0.292

0.505 Course $\times$ SES

First-Term College-Level Mathematics

0.170

0.474

Course $\times$ Ethnicity

First-Term College-Level Mathematics

0.523

0.450

Course $\times$ Gender

Ethnicity $\times$ SES

$-0.9948$

0.407

Ethnicity $\times$ Gender 
Gender $\times$ SES

Model evaluation

-2 log likelihood

Nagelkerke $R^{2}$

Standard error of the estimate
$0.933 \quad 0.509$

979.235

.503

0.481

Note. STEM = science, technology, engineering, and mathematics; URM = underrepresented minority; SES = socioeconomic status; GPA = grade point average; AP = advanced placement. ${ }^{\mathrm{a}}$ Odds ratios only presented for significant variables.

$* p<.05$. 